\title{
ISLAM DAN PANORAMA KEAGAMAAN MASYARAKAT TATAR SUNDA
}

\author{
Undang Ahmad Darsa
}

\begin{abstract}
Kepala Departemen Sejarah dan Filologi Fakultas Ilmu Budaya (FIB)
Universitas Padjadjaran Jatinangor, Bandung
\end{abstract}

\begin{abstract}
This article uses the terms "Tatar Sunda" to refer geographically to a region that stretches from the Sunda Strait (Selat Sunda/Ujung Kulon) to some of the Central Javanese territorries bordering with Cipamali/Kalipamali in Brebes in the Central Java and Kali Serayu in South of Central Java next to Cilacap. This paper argues that the religious life in the Sundanese Tatar historically and culturally took place peacefully. This paper bases this argument on the Sundanese manuscripts saying that the Hinduization process in the Tatar Sunda was mostly derived from the Hindu kingdoms' elites in the Tatar Sunda. In contrast, the process of Islamization in the Tatar Sunda was instigated from the lower classes (ordinary people). Meanwhile, some of these elites and some of the Sundanese people were able to welcome and accept Islam. Moreover, some of these Hindu elites were voluntarily converted to Islam.
\end{abstract}

\section{A. Pendahuluan}

Berdasarkan cerita rakyat dengan tanpa menyebut identitas sumbernya, Hageman (1876: 196) mengungkapkan bahwa Haji Purwa adalah orang Sunda pertama yang memeluk agama Islam dan telah mampu menunaikan syariat rukun Islam yang kelima. Ia berasal dari kalangan keluarga keraton Galuh Pakwan dan berprofesi sebagai pedagang besar sehingga tergolong kaya raya, dan tertarik masuk Islam tatkala sedang berniaga di India. Bersama istrinya, Farhana, putri saudagar muslim India, ia menunaikan ibadah haji. Selanjutnya, Haji Purwa dan keluarganya menetap di Cirebon Girang yang pada masa itu masih berada di bawah kekuasaan Galuh Pakwan. Peristiwa yang bertalian dengan Haji Purwa (1363 M) terjadi pada masa kekuasaan bercirikan pengaruh Hindu-Budha di Tatar Sunda masih kuat. Raja dan keluarga keraton Galuh Pakwan bersikap dapat menerima anggota keluarga mereka menganut agama Islam. 
Berdasarkan teks naskah Carita Parahyangan Sakéng Bhumi Jawa Kulwan Sargah 1 (CPSBJK 1), kita dapat merunut lebih jauh mengenai tokoh ini bahwa, ternyata orang yang mendapat sebutan "Haji Purwa" itu adalah salah seorang putra Prabhu Suradipati alias Rahyang Bunisora (1357$1371 \mathrm{M}$ ) yang menggantikan Prabhu Maharaja yang gugur di Bubat (13501357 M). Disebutkan bahwa dari permaisuri, Prabhu Suradipati beroleh empat orang anak, masing-masing adalah: (1) Raden Giridewata yang bergelar Kiageng Kasmaya, menjadi ratu di Cirebon Girang; (2) Raden Bratalogawa, terkenal de sebutan Haji Purwa; (3) Ratu Banawati, menjadi ratu wilayah Galuh; dan (4) Dewi Mayangsari, menjadi permaisuri Niskala Wastukancana.

Sifat terbuka dan menerima orang Islam dan agama Islam pada kalangan elit birokrat Kerajaan Sunda tampak jelas pada sikap penguasa kota pelabuhan Cimanuk (Indramayu sekarang), sebagaimana dicatat oleh Tome pires, seorang Portugis yang mendatangi kota pelabuhan tersebut tahun 1513 M. Berdasarkan berita Tome Pires (Cortesao, 1944: 183), proses Islamisasi Cirebon hingga menjadi wilayah kaum Muslimin terjadi sekitar tahun 14781. Pada waktu itulah, Syarif Hidayat tiba di Cirebon dengan dukungan Demak dan juga penguasa lokal Cirebon yang telah berkembang menjadi "supradesa". Syarif Hidayat kemudian dikukuhkan menjadi penguasa wilayah sekaligus sebagai guru agama di Cirebon. Informasi tersebut sejalan dengan yang diungkapkan sumber tradisi Cirebon, antara lain dalam teks naskah Carita Purwaka Caruban Nagari (Atja, 1972, 1986) yang menyatakan bahwa Cirebon yang penduduknya sudah muslim mulai melonggarkan diri dari keterikatan dengan Kerajaan Sunda pada tahun $1479 \mathrm{M}^{2}$.

${ }^{1}$ Tome Pires dalam bukunya Suma Oriental menggambarkan bahwa, pada awal abad ke-16 Masehi di Pelabuhan Cimanuk yang dikuasai Kerajaan Sunda, di antara penduduknya banyak yang menjadi penganut agama Islam, dan di daerah Cirebon yang ditulisnya pelabuhan Cerimon/Cheroboan merupakan pelabuhan yang baik. Di situ setiap waktu ada tiga atau empat buah jung berlabuh, dan yang terbanyak berupa lanchara (sejenis perahu yang sangat laju jalannya). Jung dapat mudik sungai yang mengalir di situ sampai kira-kira sejauh $15 \mathrm{~km}$. Pelabuhan itu berpenghuni lebih dari 1000 orang; yang diperdagangkan berupa beras dan berbagai jenis bahan pangan yang lain; jenis kayu yang diperdagangkan merupakan kayu terbaik di Pulau Jawa. Pelabuhan yang lain adalah Japura yang terletak antara Cirebon dan Losari, berpenduduk 2000 orang yang tersebar di dusun-dusun (Cortesao, 1944).

${ }^{2}$ Situasi ini terjadi pada masa pusat aktivitas politik kekuasaan Sunda di Galuh Pakwan dipinpin Rahiyang Dewa Niskala yang memerintah selama 7 tahun (1475-1482 M). Dalam Carita Parahiyangan $(C P)$, ia bergelar Tohaan di Galuh, sedangkan di dalam piagam Kebantenan Bekasi $E 42 a-b$, ia bergelar Rahiyang Ningrat Kancana. Adapun dalam prasasti Batutulis Bogor, ditulis bahwa Rahiyang Dewa Niskala ialah yang wafat di Guna Tiga, akan tetapi Tohaan di Galuh yang tercantum dalam Carita Parahiyangan itu wafat di Gunung Tiga, sehingga 'guna tiga' merupakan salah pahat 
Adalah sebuah catatan kisah perjalanan seorang tokoh bernama Prebu Jaka Pakuan alias Rakeyan Ameng Layaran atau lebih dikenal dengan nama Bujangga Manik. Ia adalah seorang keluarga keraton Pakwan Pajajaran yang dua kali melakukan perjalanan darat dari ibukota Pakwan Pajajaran (kota Bogor sekarang) menyusuri pantai utara Pulau Jawa pada akhir abad ke-15 M dan kembali ke Tatar Sunda melalui wilayah selatan Pulau Jawa. Kisah perjalanan ini diabadikan dalam sebuah naskah lontar beraksara dan berbahasa Sunda Kuno berjudul Kisah Perjalanan Bujangga Manik. Dalam perjalanannya itu, Bujangga Manik sengaja berkunjung ke tempat-tempat suci keagamaan (rabut) bernuansa Hindu-Budha yang terletak di Jawa Tengah juga di Jawa Timur. Ia sepertinya menghindari singgah di kota Cirebon, bahkan menyebutkannya pun tidak, padahal rute perjalanannya melalui daerah sebelah utara Gunung Ciremai. Boleh dikatakan mustahil bila Bujangga Manik tidak tahu kota pelabuhan Cirebon yang cukup besar serta ramai saat itu, padahal ia menyebut Gunung Ciremai dan beberapa nama tempat kecil yang terletak di sebelah selatan Cirebon, seperti Timbang, Kuningan, Luhur Agung (Luragung), dan Darma. Semua tempat itu berada di daerah Kabupaten Kuningan sekarang.

Maksud kunjungan Bujangga Manik tersebut sepertinya dalam rangka penyusunan naskah keagamaan. Ia perlu membaca dan menyalin beberapa teks naskah keagamaan yang mungkin tersimpan di berbagai tempat suci atau pertapaan, seperti, mandala dan kawikuan yang masih ada waktu itu. Dalam abad ke-15 M kegiatan keagamaan di beberapa tempat pedalaman Jawa Tengah dan Jawa Timur nampaknya masih tetap berlanjut. Hal itulah yang masih menjadi perhatian bagi para pendeta Sunda, sehingga Bujangga Manik melakukan perjalanan jauh keliling Pulau Jawa, bahkan ke Pulau Bali dalam upaya mendapat masukan perihal kaidah keagamaan yang masih ada di Jawa Tengah dan terutama Jawa Timur, wilayah tempat berdirinya Kerajaan Majapahit yang pernah mengalami masa kejayaannya.

untuk 'gunung tiga'. Mungkin itulah sebabnya penulis $C P$ tampak kurang begitu puas terhadap Tohaan di Galuh sehingga dinyatakan termasuk yang: salah na twah bogoh ka éstri larangan ti kaluaran 'keliru berperilaku sebab mencintai isteri terlarang dari luar'. Bahkan, dalam Nagarakretabhumi I.5 (Atja \& Ayatrohaédi, 1986: 108) ditegaskan, mapan sira mastri lawan wanodya sakéng Wilwatikta $i$ bhumi Jawa Wétan, matangyan sira sinapa prawrēttinya, mapan ika pamali 'karena dia beristerikan wanita dari Wilwatikta di wilayah Jawa Timur, sehingga perbuatannya mendapat kutukan, sebab hal itu tabu'. Di satu pihak bisa jadi, bahwa yang dimaksud: éstri larangan ti kaluaran 'isteri terlarang dari luar' $(C P)$ atau wanodya sakéng Wilwatikta i bhumi Jawa Wétan 'wanita dari Wilwatikta di wilayah Jawa Timur' (Nkbm I.5) itu ialah seorang "perempuan yang sudah muslim”. 
Memang tempat yang dikunjungi dan disebutkan namanya oleh Bujangga Manik itu terutama tempat-tempat keagamaan yang bernuansa Hindu-Buda, akan tetapi nama wilayah Demak yang tentu sudah Islam disebutnya. Demikianlah Bujangga Manik mencatat (baris 80-85):

Sadatang ka tungtung Sunda, meuntasing di Cipamali, datang ka alas Jawa. Ku ngaing geus kaideran, lurah-lirih Majapahit, palataran alas Demak.

'Sesampainya ke perbatasan Sunda, kuseberangi sungai Cipamali, tibalah ke wilayah Jawa. Semua telah kujelajahi, beberapa daerah Majapahit, pedataran wilayah Demak'.

Dengan demikian, kita dapat mengetahui bahwa Sunda, dan Jawa dalam hal ini kerajaan Majapahit masih eksis, tetapi Demak pun tampak sudah muncul ${ }^{3}$. Namun, ketika melewati sekitar Cirebon, pandangan Bujangga Manik sepertinya diarahkan ke selatan dan tak pernah menengok ke utara, bahkan rute perjalanannya pun makin menjauh ke pedalaman. Selain itu, ia sama sekali tidak menyebut adanya agama atau penganut agama Islam, baik di Tatar Sunda maupun di Tatar Jawa. Padahal pada waktu itu sudah banyak pemeluk agama Islam berdatangan dan menetap di pesisir utara Pulau Jawa dengan mata pencaharian berdagang. Tatkala pulang dari perjalanan pertama, ia menumpang kapal milik pedagang Malaka dari pelabuhan Pemalang dan begitu dihormati oleh kapten kapalnya yang sangat mungkin sudah beragama Islam.

Dalam pertemuannya dengan orang asing, Bujangga Manik hanya menyebut identitas negeri dan bangsanya (Bali, Baluk, Bangka, Barus, Bugis, Cina, Jambi, Jawa, Keling, Lampung, Makasar, Malaka, Malayu, Pasay, Salembu), sama sekali tidak menyebut identitas agamanya, padahal ia sendiri seorang penganut agama yang taat dan sedang dalam perjalanan ziarah ke tempat-tempat suci keagamaan serta kemudian mengabdikan dirinya dalam kegiatan keagamaan dengan menetap di beberapa pertapaan (titrayatra, batur, rabut) di Tatar Sunda sampai akhir hayatnya. Dengan demikian, Bujangga Manik dalam kehidupan beragama bersikap tidak ambil perduli dengan agama orang lain (sikap: "bagimu agamamu, bagiku agamaku"), melainkan hanya memusatkan perhatian kepada agama yang dianutnya sendiri. Begitu pula penyusun naskah Sanghiyang Siksakandang

\footnotetext{
${ }^{3}$ Pada tahun 1397 Saka (1475 M) Raden Patah diangkat menjadi Adipati Demak. Tiga tahun berikutnya (1478 M), Raden Patah melenyapkan prabhawa Wilwatikta dengan dukungan para guru agama, yaitu para Wali Sanga. Dengan demikian, catatan kisah perjalanan Bujangga Manik itu bisa jadi dilakukan pada sekitar tahun tersebut.
} 
Karesian (SSK) yang selesai ditulis pada tahun 1518 M mencatat berbagai hal yang bertalian dengan kebudayaan Sunda masa itu, namun sama sekali tidak menyinggung tentang agama Islam, padahal pada masa itu sudah banyak warga Kerajaan Sunda yang telah memeluk agama Islam, seperti diberitakan Tome Pires di muka.

Sikap pemimpin agama di Kerajaan Sunda terhadap Islam tampak pada teks naskah Carita Parahyangan (CP) yang disusun tidak lama (akhir abad ke-16 M) sesudah Kerajaan Sunda runtuh (1579 M). Pengarangnya sendiri tampaknya seorang pertapa yang bermukim di wilayah Galuh Pakwan (daerah sebelah timur Sungai Citarum), tetapi mempunyai hubungan dekat dengan lingkungan keraton Kerajaan Sunda di Pakwan Pajajaran. Penulis CP ini bersikap kritis terhadap 4 orang raja Sunda terakhir yang dipandang sebagai pihak yang bertanggung jawab atas kehancuran Kerajaan Sunda ${ }^{4}$. Sikap penulis CP terhadap Islam bukan ditujukan kepada Islam sebagai agama, melainkan Islam sebagai kekuatan politik yang dijalin dengan Demak dan Cirebon. Dalam akhir karangannya dinyatakan:

Tembey datang na prebéda. Metu sanghara ti Selam. Pahi éléh ku Selam. Kitu, kawisésa ku Demak deung ti Cerbon, pun.

'Lalu terjadi perubahan. Datang bencana dari Islam. Semua kalah oleh Islam. Begitulah akhirnya ditundukkan oleh Demak dan Cirebon, maklumkanlah.

Terhadap 4 orang raja Sunda terakhir, penulis naskah CP menunjukkan sikap ketidakpuasannya dalam hal menyikapi hembusan perubahan terjadinya gejolak geo-politik, ekonomi, dan budaya di Nusantara pada seputar abad ke-15 M, ketika sistem kerajaan bergerak menuju ke arah sistem kesultanan di bawah pengaruh yang tidak kalah kencangnya dari sistem sekuler barat ${ }^{5}$. Namun secara tersirat, penulis naskah CP mengakui

\footnotetext{
${ }^{4}$ Dalam naskah itu tercatat penggunaan empat kosa kata bahasa Arab, yaitu niat, dunya, selam, dan tinja yang menunjukkan budaya Arab-Islam sudah mulai masuk ke dalam masyarakat Sunda, betapapun kecilnya. Islam disebutnya dengan istilah selam.

${ }^{5}$ Penulis CP menyindir, (1) Prabu Ratu Dewata alias Ratu Dewatabuana (1535-1543 M) dengan mengatakan: "Maka berhati-hatilah yang kemudian, jangan berpura-pura rajin puasa. Padahal itu tidak setulus hati”. Penggantinya ialah (2) Sang Ratusaksi Sang Mangabatan (1543-1551 M) dikecam sebagai raja yang berperilaku buruk: "sebab raja kena musibah oleh isteri yang telah tunangan dari luar dan oleh ibu tiri. Ia membunuh orang-orang tak bersalah, merampas hak rakyat tanpa perasaan, tidak berbakti kepada orang tua, menghina para pendeta. Janganlah ditiru oleh yang kemudian perilaku raja ini”. Raja Sunda selanjutnya adalah (3) Tohaan di Majaya alias Prebu Nilakendra, dikenal sebagai sang mokténg Majaya (1551-1567 M) yang dinyatakan oleh penulis CP: "Sang Nilakendra kerjanya tiada lain kecuali bersenang-senang selamanya, akhirnya menyebar kemaksiatan. Mempunyai anak perhatiannya hanya tertumpu kepada kenikmatan duniawi.
} 
bahwa proses islamisasi di Tatar Sunda umumnya berlangsung damai, kecuali di 9 lokasi, yaitu Rajagaluh (di Majalengka), Kalapa (Jakarta), Pakwan (Bogor), Galuh (Ciamis), Datar (Banjar?), Madiri (Mandirancan?), Jawakalapa (?), Gegelang (Pandeglang), dan Salajo (?). Islam tidak dinyatakan sebagai musuh, tetapi hanya dipandang sebagai pihak yang mendatangkan bencana. Runtuhnya keseluruhan Kerajaan Sunda tidak semata-mata disebabkan oleh kekuatan Islam, melainkan terutama disebabkan oleh kelemahan di dalam kerajaan itu sendiri yang berjalan cukup lama (44 tahun). Meskipun demikian, Kerajaan Sunda masih bisa bertahan selama lebih dari 50 tahun dibandingkan dengan waktu keruntuhan Kerajaan Majapahit.

Sejalan dengan informasi tersebut, keterangan yang berasal dari pihak Islam pun mengakui bahwa proses islamisasi di Tatar Sunda pada umumnya berjalan secara damai, kecuali bagi daerah Rajagaluh dan Talaga (Majalengka), Pakwan (Bogor), dan Gunung Karang (Banten) ${ }^{6}$. Dituturkan lebih jauh bahwa islamisasi di Tatar Sunda diawali oleh kegiatan perguruan agama Islam di bawah asuhan ulama pendatang, seperti Syekh Quro (di Karawang); Syekh Nurjati, Syekh Datuk Kahpi dan kemudian Syarif Hidayatullah alias Sunan Gunungjati (di Cirebon) ${ }^{7}$; Maulana Hasanuddin (di Banten); Syekh Abdulmuhyi (di Pamijahan, Tasikmalaya); Syekh Dul'arif (di Cangkuang Garut); Sunan Godog (di Suci Garut); Sunan Cikadueun (di Pandeglang); Aria Wangsagoparana (di Sagalaherang Subang). Lokasi dan peninggalan kegiatan mereka dianggap keramat dan banyak diziarahi orang hingga masa sekarang.

Dari pihak kaum Musliminnya pun, proses islamisasi dilakukan melalui pendekatan budaya terhadap penganut agama lama, sepeti tercermin

\footnotetext{
Melengserkan pertapa, cucu saudara tirinya. Air yang memabukan dijadikan pelezat makan dan minum. Peladang rakus akan makanan. Tidak sadar akan kewajiban bercocok tanam. Terlalu lama raja tergoda oleh makanan. Tidak ada ilmu yang disenanginya kecuali makan yang serba lezat, yang pantas untuk ukuran kekayaannya". Pada masa pemerintahan raja Sunda terakhir, (4) Nusiya Mulya alias Prabu Ragamulya Suryakancana alias Pucuk Umun Pulasari (1567-1579 M), terjadi perubahan perilaku orang dari kehalusan budi tenggelam ke dalam keserakahan nafsu, (bwana alit sumurup ring ganal) sehingga kerajaan Sunda runtuh digantikan oleh Cirebon.

${ }^{6}$ Berdasarkan sumber tradisi Cirebon, seperti Babad Cirebon (Darsa, 1986), sumber tradisi Banten seperti Babad Banten (Djajadiningrat, 1913, 1983), dan sumber tradisi Priangan seperti Carita Prabu Kéan Santang (Darsa, 1994).

${ }^{7}$ Seikh Datuk Kahfi, yang dalam cerita rakyat sebagai orang pertama yang membuka pesantren di Gunung Amparan Jati, ialah menantu Haji Purwa. Bahwa di daerah itu pada awal abad ke-15 Masehi telah terdapat kelompok penghuni yang beragama Islam, dapat kita ketahui dari Carita Purwaka Caruban Nagari (CPCN) karya Pangeran Arya Carbon, tahun 1720 Masehi (Atja, 1972, 1986).
} 
dengan pengakuan dalam cerita legenda, antara lain, Babad Cirebon bahwa, Syarif Hidayatullah alias Sunan Gunungjati, penyebar agama Islam dan penegak kekuasaan Islam di Tatar Sunda yang berpusat di Cirebon, secara genealogis masih keturunan (cucu) Prabu Siliwangi, raja Sunda termashur dan terakhir ${ }^{8}$. Muncul pula cerita legenda di wilayah Priangan yang berjudul Carita Prabu Kéan Santang atau dalam judul Babad Godog bahwa, islamisasi di daerah pedalaman Tatar Sunda dilakukan oleh Kean Santang, putera Prabu Siliwangi, walaupun ayah dan sebagian rakyatnya menolak masuk Islam. Sementara, Kean Santang sendiri diislamkan langsung oleh Nabi Muhammad melalui pertarungan ketinggian ilmu kedigjayaan dengan Bagenda Ali (Ali bin Abi Thalib; sahabat, saudara sepupu, sekaligus menantu Nabi).

Dalam hubungan ini perlu dicermati bahwa, berdasarkan data tradisi naskah Sunda tampak jika proses hinduisasi di Tatar Sunda umumnya bermula dari kalangan atas atau elit keraton, sebaliknya proses islamisasi bermula dari kalangan bawah atau rakyat biasa. Jika kalangan rakyat biasa terbatas jumlahnya yang menerima agama Hindu-Budha karena mereka kebanyakan mempertahankan keyakinan lamanya ajaran Jatisunda (Sunda Wiwitan) yang memuja Hyang Tunggal, maka agama Islam di samping diterima oleh masyarakat kecil, juga selanjutnya diterima pula oleh kalangan elit.

Sebagian kalangan elit dan rakyat Sunda bersikap dapat menerima agama Islam dan dengan sukarela mereka masuk Islam. Di samping itu, jika terhadap ajaran agama Hindu-Budha muncul ketidakpuasan di kalangan orang Sunda, mereka mencari alternatif lain dan kembali kepada ajaran Jatisunda sebagai jalan keluarnya. Akan tetapi, terhadap ajaran Islam tidak muncul ketidakpuasan yang demikian sehingga tidak terjadi peralihan agama secara berarti dari sudut kuantitas dan kualitas 9

\footnotetext{
${ }^{8}$ Berdasarkan teks naskah CPSBJK. IV, diriwayatkan tentang nenek moyang para Sultan Cirebon berawal dari Sri Baduga Maharaja yang disebut juga sebagai Prabu Siliwangi. Ia beristrikan Subanglarang atau Subangkerancang yang dari pernikahannya berputra beberapa orang, di antaranya Pangeran Walangsungsang dan Nyai Lara Santang. Kedua putra-putri itu pernah berguru kepada Seikh Datuk Kahfi, kemudian bergabung dengan Ki Gedéng Alangalang dan membangung pedukuhan yang selanjutnya berkembang menjadi Kota Cirebon. Menurut naskah Nagarakertabhumi (Atja \& Ayatrohaédi, 1986: 46), awal mula perambahan hutan untuk membangung pedukuhan itu tercatat pada 14 kresnapaksa (parogelap) cetramasa 1367 Saka (=9 April $1455 \mathrm{M})$. Penduduk yang mula-mula bermukim di situ berjumlah 52 orang dengan bermata pencaharian siang malam menangkap ikan di sungai atau di pesisir laut di sebelah timur tempat tinggalnya.

${ }^{9}$ Menurut sebagian pengamat memang pernah ada gejala ketidakpuasan di kalangan sekelompok kecil kaum muslimin, seperti ditandai dengan munculnya agama Jawa-Sunda atau
} 
Dalam hubungan ini, jika penganut agama Hindu-Budha serta ajaran Jatisunda secara masal beralih agama menjadi penganut Islam $^{10}$, namun kaum muslimin dan muslimat Sunda umumnya cenderung menolak berganti agama, ketika kepada mereka diperkenalkan agama lain oleh orang Barat. Hingga sekarang agama Islam dianut oleh lebih dari $90 \%$ orang Sunda dan banyak mempengaruhi alam pikiran, perasaan, perilaku, dan pola hidup mereka sehari-hari.

\section{B. Islam Sebuah Panorama Keabadian}

Mengapa lapisan orang Sunda umumnya menerima Islam sebagai agama anutan mereka? Mengapa pula orang Sunda terus memegang teguh agama Islam sebagai agama anutan mereka? Jawaban yang memuaskan atas dua pertanyaan tersebut tentu harus didekati secara multidimensi karena masalahnya kompleks yang meliputi keseluruhan hidup orang Sunda, baik secara individual maupun komunal serta meliputi rentang waktu yang panjang dan wilayah yang cukup luas. Sebagai langkah awal, dua pertanyaan tersebut dicoba dijawab melalui sudut pandang filologis dan sepintas perbandingan ajaran agama dan pelaksanaannya dalam kehidupan budaya mereka. Dalam hal ini, akan diperbandingkan antara ajaran yang dinamai Jatisunda (Sunda Wiwitan) yang dijadikan pedoman hidup orang Sunda masa pra-Islam dengan ajaran agama Islam yang bertalian dengan konsep-konsep: ketuhan, alam semesta, kehidupan sesudah mati, sistem pilihan ganda dalam menjalani hidup manusia, dan tapa atau amal.

\section{Konsep Keesaan Tuhan}

Orang Sunda masa pra-Islam dalam pengembaraan mencari Tuhan telah menemukan Hyang Tunggal sebagai Tuhan mereka. Hyang itu, menurut mereka adalah Dzat Tunggal Maha Gaib yang menciptakan, menguasai, dan menentukan kehidupan manusia dan kehidupan alam pada umumnya. Sebutan lain untuk Hyang dalam kehidupan sehari-hari tercermin dalam julukanNya, antara lain: Batara Séda Niskala (Yang Gaib), Batara Tunggal (Yang Maha Esa), Hyang Keresa (Yang Maha Kuasa), Batara Jagat Nata (Yang Menguasai Alam Semesta), Hyang Manon (Yang Maha Melihat)

\footnotetext{
Madraisme di Cigugur (Kuningan) dan aliran kepercayaan Perjalanan di Bandung pada awal dan pertengahan abad ke-20 M, akan tetapi kedua kasus tersebut bukan disebabkan oleh ketidakpuasan terhadap ajaran agama, melainkan ketidakpuasan terhadap lingkungan sosialnya.

${ }^{10}$ Kecuali kelompok masyarakat Kanekes (Baduy) di pedalaman Banten.
} 
yang dalam ajaran agama Islam secara jelas dikemukakan dalam Asma'ul husna. Mereka pun menjalankan ajaran sendiri, ajaran keyakinan, tata cara peribadatan kepada Hyang, dan etika kehidupan keagamaan yang mereka namai agama Jatisunda atau menurut orang Kanekes (Baduy) adalah ajaran Sunda Wiwitan atau Selam Wiwitan.

Setidaknya dapat dipastikan bahwa, masyarakat Sunda pada zaman sistem kerajaan tentunya mengenal ajaran Hindu-Budha, seperti halnya masyarakat Jawa pada zaman yang sama. Hanya saja tidaklah dapat diketahui tingkat kedalaman mereka dalam beragama tersebut. Hal yang menarik berdasarkan berita naskah Sunda Kuno adanya gejala campuran agama Hindu-Śiwa-Budha dijalin dengan "agama pribumi". Tokoh transenden "Hyang" yang tentunya berasal dari konsep agama pribumi, dibedakan dengan tokoh-tokoh dewata Hindu-Budha. Ternyata kedudukan dewa lebih rendah daripada hyang. Lebih lanjut dalam naskah SSK yang digubah tahun $1518 \mathrm{M}$ disebutkan, bahwa: .. mangkubumi bakti di ratu, ratu bakti di déwa, déwa bakti di hyang,... 'mangkubumi tunduk kepada raja, raja tunduk kepada dewa, dewa tunduk kepada hyang'.

Di dalam naskah Tantu Panggelaran yang berasal dari Jawa Timur tersirat kesan bahwa kebudayaan India lebih rendah kedudukannya daripada kebudayaan Jawa ${ }^{11}$. Hal yang sama juga dijumpai dalam naskah Korawāśrama ${ }^{12}$ yang digubah dalam kisaran waktu yang sezaman (abad ke$16 \mathrm{M})$ dengan SSK dan Tantu Panggelaran. Hal ini menunjukkan bahwa pada sekitar abad ke-15 M hingga awal abadke-16 M anasir Hindu-Budha makin terdesak oleh anasir Nusantara.

Berkenaan dengan sebutan Hyang Manon itu jelas tersurat dalam teks naskah Sang Hyang Hayu $(S H H)^{13}$ memiliki sebelas sifat, yaitu: (1) acintya 'tak terperkirakan', (2) adresya 'tak terjangkau penglihatan', (3) abyapadesa 'tak terjangkau tempatnya', (4) adwaya 'tak ada duanya', (5) awijnyana 'tak

${ }^{11}$ Dalam Tantu Panggelaran terdapat kisah Mpu Barang yang berkunjung ke Jambudwipa (India). Ia di sana melihat para pendeta India menyembah dewa Haricandana (Wisnu). Mpu Barang diminta untuk menyembah pula, namun ia menolaknya karena ia pendeta Jawa. Para pendeta India marah lalu menyerang Mpu Barang, tetapi tak satu pun yang dapat mengalahkannya (Pigeaud, 1924: 114-115).

${ }^{12}$ Korawāśrama menguraikan bahwa Mpu Mahapalyat pergi ke India. Ia di sana dipaksa menyembah arca Candani, namun ketika Mpu Mahapalyat menyembahnya, arca Candani itu tiba-tiba pecah (Swellenggrebel, 1936: 66-68).

${ }^{13}$ Naskah Sunda Kuno yang berjudul Sang Hyang Hayu berbahan daun nipah ditulis pada tahun panyca warna catur bumi (1445 Saka/1523 Masehi). Lihat tesis Undang A. Darsa, Pascasarjana Unpad, 1998. 
terjangkau oleh ilmu pengetahuan, 'mahapandai', (6) awimohita 'tak kebingungan', (7) awarna 'tak berwujud rupa, bentuk, jenis kelamin', (8) awasta 'tak berasal-usul', (9) awacya 'tak terkatakan', (10) prabutarebawa 'raja dari segala raja mahakuasa', dan (11) atyantarebawa 'mahakekal abadi'.

Ternyata rumusan dan sifat-sifat Hyang itu memiliki beberapa persamaan makna dan gambaran dengan rumusan makna dan gambaran Tuhan dalam ajaran agama Islam; yang berbeda menyangkut istilahistilahnya semata. Dalam agama Islam, kita diperkenalkan dengan 20 sifat Allah, yakni: (1) wujud 'ada', (2) qidam 'tidak berpermulaan', (3) baqaa 'kekal', (4) mukhaalafatuhu lilhawadits 'berbeda dengan segala yang baru', (5) qiyaamuhu binafsihi 'ada dengan sendirinya', (6) wahdaniyah 'tunggal, esa', (7) qudrat 'kuasa', (8) iraadat 'berkehendak',(9) ilmu 'pandai,', (10) hayaat 'hidup', (11) samá 'mendengar', (12) bashar 'melihat', (13) kalaam 'berkata-kata', (14) qaadirun 'kuasa', (15) muriidun 'yang berkehendak', (16) áalimun 'mengetahui', (17) hayuun 'hidup', (18) samiiun 'mendengar', (19) bashiirun 'melihat', dan (20) mutakallimun 'berkata-kata'.

Yang paling prinsipil ialah keyakinan bahwa Tuhan itu ada dan hanya satu. Dalam ajaran Jatisunda, hal itu disifatkan dengan sebutan adwaya 'tak ada duanya' dan dalam agama Islam dirumuskan dalam ungkapan Allahu Ahad 'Tuhan Yang Maha Esa'. Keberadaannya dalam wujud gaib, yang dalam ajaran Jatisunda disebut awasta 'tak berasal-usul' dan dalam agama Islam disebut bersifat Wujud adh-Dhohiru wal-Baatinu. Begitu pula mengenai keyakikan bahwa Tuhan itu adalah awarna 'tak berwujud rupa, bentuk, jenis kelamin' yang dalam Islam disifati sebagai Khaliq (pencipta alam semesta), bukan makhluq (hasil ciptaan, alam semesta beserta isinya, termasuk manusia), dan jadi dengan sendiriNya (kiyamuhu binnafsihi), tidak diciptakan oleh yang lain. Tuhan itu adalah Maha Kuasa, menguasai alam semesta, Rabb al-'alamin, yang dalam ajarana Jatisunda disebut prabutarebawa 'raja dari segala raja mahakuasa'. Tuhan diimani Maha Berkehendak, jika menghendaki sesuatu, hanya difirmankan: "Jadi!", maka "Jadilah" (Kun fayakun), yang dalam ajaran Jatisunda disifati awijnyana 'mahapandai, tak terjangkau oleh ilmu pengetahuan'.

\section{Konsep Alam Semesta}

Dalam konsep ajaran orang Sunda pra-Islam, sebagaimana digambarkan dalam naskah $\mathrm{SHH}$, tata ruang jagat (kosmos) terbagi menjadi 
tiga susunan, yaitu: (1) susunan dunia bawah, saptapatala 'tujuh neraka', (2) buhloka adalah bumi tempat kita berada saat ini yang disebut madyapada; dan (3) susunan dunia atas, saptabuana atau buanapitu 'tujuh sorga'. Jadi, di antara saptapatala dan saptabuana disebut madyapada, yakni pratiwi 'dunia tempat manusia'.

Saptapatala itu susunan bentuknya bagaikan kerucut tengadah, yang terdiri atas tujuh neraka: patala, nitala, sutala, talantala, talaningtala, mahatala, dan atyanta artapatala 'neraka terdalam yang sangat mengerikan'. Sedangkan susunan Saptabuana atau Buanapitu menyerupai keadaan sarang lebah berbentuk labu, terdiri atas tujuh sorga: buwahloka, suwahloka, janahloka, tapwaloka, satyaloka, mahaloka, dan atyanta artaloka 'sorga tertinggi'.

Setelah saptabuana masih ada tempat tujuh susun yang bersuasana "sunyi-hampa", yaitu sunya, atisunya, paramasunya, atyantasunya, nirmalasunya, suksmasunya, dan acintyasunya. Di atasnya lagi adalah tujuh susun yang berupa tempat "kesirnaan-lenyap", yaitu taya, atitaya, paramataya, atyantataya, nirmalataya, suksmataya, dan acintyataya. Kemudian, di atas tempat tersebut masih ada tempat yang dinamakan abyantarataya 'bagian terdalam kesirnaan'. Abyantarataya artinya tidak dapat terjangkau oleh cahaya bintang, rembulan, matahari, pelangi, bianglala, kabut, asap, awan, hujan, petir, halilintar, guruh, guntur, meteor, paramanuh 'partikel-partikel kecil, atom', dan berbagai suara mahluk hidup. Semua itu tidak akan pernah sampai ke sana.

Setelah abyantarataya adalah pancatanmantra 'lima unsur halus' yang antara lain terdiri atas buddi 'hikmah kebijakan', guna 'kepandaian', pradana 'kesalehan'. Di atas itu terdapat sunyataya nirmala 'kesunyisenyapan suci abadi'; dan berakhir pada kanirasrayan 'kemahakuasaan, kebebasan tertinggi', yakni "takdir". Sesungguhnya di atas itu semua masih ada alam lain yang suasananya makin hening yang paling tinggi adalah alam kahiyangan, yakni jatiniskala (kemahagaiban tertinggi, alam transendental) tempat bersemayam Hyang Tunggal Wisésa yang tidak diperuntukan bagi segala yang diciptakanNya. Gambaran alam semesta seperti demikian didapatkan pula dalam ajaran agama Islam, misalnya, sebagaimana terdapat dalam kisah peristiwa Mi'raj Nabi Muhammad saw.

\section{Konsep Kematian}

Ajaran keagamaan orang Sunda masa pra-Islam mengungkapkan adanya peristiwa kematian yang dialami manusia dalam hidup di dunia, yaitu terlepasnya rokh dari tempatnya pada raga. Peristiwa tersebut dinamai kaleupasan. Bagi orang yang selalu melakukan hubungan dengan Hyang melalui upacara-upacara ritual serta sikap dan perilaku selama hidup di dunia 
baik dan mengikuti tuntunan ajaran agamanya, maka peristiwa kaleupasan akan berlangsung dengan tenang dan kemudian segera diikuti moksa, yaitu rokhnya naik ke atas menuju alam kanirasrayan. Bagi orang yang tak pernah atau jarang melakukan syariat pemujaan terhadap Hyang serta sikap dan perilaku selama hidup di dunia buruk atau sering melakukan kejahatan dan melanggar ajaran agama, maka peristiwa kaleupasannya berlangsung dahsyat dan mengerikan serta rokhnya turun ke alam saptapatala 'neraka'.

Contoh peristiwa kaleupasan dan moksa dituturkan dalam naskah Séwaka Darma (SD), bahwa bagi yang sida-moksa selalu terbuka jalan baginya untuk masuk nirwana 'sorga tertinggi'. Moksa berarti bebas dari ikatan dunia dan leupas berarti bebas dari dunia dan pribadi. Dalam naskah SSK diungkapkan bahwa orang yang akan menjadi penghuni neraka (kawah si mregawijaya) itu, antara lain, lelaki yang suka menyelinap ke rumah wanita lalu berbuat serong, wanita yang merasai pria yang bukan suaminya, pria yang merasai wanita yang bukan istrinya.

Selanjutnya, ajaran Jatisunda menuturkan pula adanya kehidupan manusia di alam sesudah terjadi kematian (kaleupasan). Kesenangan atau kesengsaraan hidup di alam sana (niskala 'alam gaib') ditentukan oleh amal perbuatan manusia selama hidup di dunia. Jika amal perbuatannya baik atau banyak melakukan kebaikan menurut tuntunan ajaran hidup yang berlaku, maka akan mengalami kesenangan di alam sananya yang disebut sorga. Sebaliknya, jika perilaku seseorang selama hidup di dunia buruk, artinya banyak melakukan kejahatan dan melanggar ajaran Sanghiang Siksa (agama), maka ia akan mengalami kesengsaraan di alam sananya yang disebut naraka.

Peristiwa kaleupasan dalam Islam disebut sakratul maut. Lebih jauh dalam kitab suci al-Qur'an, sumber primer ajaran agama Islam dikemukakan bahwa setiap yang bernyawa, tentu termasuk manusia, akan mengalami maut atau kematian (Kullu nafsin daikatul maut). Dalam Islam pun ada gambaran suasana yang tenang dan mengerikan dalam proses sakratul maut yang ditentukan oleh amal ibadah yang bersangkutan selama hidupnya di dunia. Setelah mengalami sakratul maut, rokh manusia akan masuk ke alam barjah dan akan terus berada di situ sampai tiba hari kiamat.

Pada hari kiamat, rokh manusia akan dihidupkan kembali dan dikumpulkan serta diadili atau diperiksa dan ditimbang amal ibadahnya secara individual. Jika amal ibadahnya (kebaikan) lebih berat timbangannya 
maka ia akan masuk jannatun naim (surga tertinggi) yang dalam ajaran tradisi orang Sunda adalah atyanta artaloka (surga tertinggi) sebagai ganjarannya. Sebaliknya, jika perbuatan dosa dan perilaku buruk yang lebih berat timbangannya atau lebih banyak, maka ia akan dimasukkan ke dalam naari jahannama (neraka jahanam) yang dalam ajaran Sunda adalah atyanta artapatala (neraka terdalam yang sangat mengerikan) sebagai hukuman.

\section{Konsep Pilihan Ganda}

Hal lain yang mencerminkan persamaan antara ajaran agama orang Sunda masa pra-Islam dengan ajaran agama Islam yang perlu pula dikemukakan ialah mengenai sistem pilihan ganda yang dapat menentukan pilihan baik atau buruk dampak perjalanan hidup manusia di dunia (sakala) ini dan di akhirat (niskala) kelak. Dalam menempuh perjalanan hidup di dunia, bagi manusia disediakan dua macam jalan pilihan, yaitu jalan yang baik-benar dan jalan yang buruk-salah menurut ajaran agama dan etika hidup.

Manusia diberi kesempatan untuk memilih salahsatu dari dua jalan tersebut. Jika memilih jalan yang baik-benar, maka ia akan memetik buah kesejahteraan dan kebahagiaan hidup di dunia (sakala) dan di alam pascadunia atau alam akhirat (niskala). Sebaliknya, jika yang dipilih itu jalan yang buruk-salah, maka ia akan merasakan kesengsaraan dan penyesalan hidup di dunia dan terutama di alam akhirat kelak. Sebagai bekal hidup di dunia manusia dianugerahi perlengkapan yang sempurna, baik raga (jasmani) maupun nyawa (rokhani).

Pada masa pra-Islam, orang Sunda dijari konsep yang disebut dasakreta 'sepuluh kesejahteraan'. Seseorang bisa mencapai kesejahteraan dan kebahagiaan, apabila dia dapat memfungsikan dasa indria (telinga, mata, kulit, lidah, hidung, mulut, tangan, kaki, dubur, dan kemaluan) secara baik dan benar, yakni sesuai dengan fungsi yang sesungguhnya dan ajaran agama. Akan tetapi, bila dasa indria itu difungsikan kepada hal-hal buruk atau salah (tak sesuai dengan fungsi sesungguhnya), maka akan berdampak orang itu mengalami kesengsaraan dan kehinaan. Rumusan ajarannya, misalnya, bagi indera telinga berbunyi: Ceuli ulah barang déngé mo ma nu sieup didéngé kénana dora banyacana, sangkan urang nemu mala na lunas papa naraka; héngan lamun kapahayu ma sinengguh utama ti pangreungeu 'Telinga jangan mendengar yang tidak layak didengar, karena menjadi pintu bencana, 
penyebab kita mendapat celaka di dasar kenistaan neraka; namun kalau telinga terpelihara, kita akan mendapat keutamaan dari pendengaran'. Begitu pula bagi kesembilan indera lainnya.

Di dalam Islam pun, al-Qur'an berulangkali mengemukakan bahwa manusia diberi kebebasan untuk memilih salahsatu dari dua jalan yang disediakan oleh Allah SWT. Bila memilih jalan lurus, berupa melaksanakan perintah dan mencegah larangan Allah sebagaimana tertera dalam ajaran agama Islam (taqwa), maka ganjarannya jannatun naim. Sebaliknya, bila yang dipilh itu jalan bengkok, berupa melanggar perintah dan mengerjakan larangan Allah, maka dia akan menerima siksa api neraka sebagai hukuman atas perbuatanya.

\section{Konsep Tapa atau Amal}

Tapa dalam konsep orang Sunda bukan hanya mengandung pengertian melakukan upacara ritual keagamaan atau kegiatan keagamaan lainnya di kabuyutan (tempat sakral), seperti di: titrayatra, batur, mandala, kawikuan, melainkan pada dasarnya bermakna melakukan aktivitas pekerjaan atau melaksanakan kewajiban sebaik-baiknya sesuai dengan tugas, profesi atau pekerjaan masing-masing. Tapa dilakukan oleh siapa pun, seperti: prabu, rama, resi, pandita, petani, prajurit, pedagang, pria, wanita, orang tua, anakanak, para siswa.

Seorang pendeta yang mendidik muridnya dengan baik, sungguhsungguh, dan ikhlas sehingga muridnya itu menjadi orang cerdas dan saleh, maka ia telah melakukan tapa dengan sempurna. Begitu pula seorang pejabat negara yang melaksanakan tugas dan kewajibannya dengan baik, sungguh-sungguh, dan ikhlas sehingga kesejahteraan hidup masyarakat terwujud secara adil, maka ia telah melakukan tapa dengan sempurna.

Kualitas tapa seseorang dan hasil yang bisa diperolehnya ditentukan oleh tingkat kebenaran, kesungguhan, dan keikhlasan dalam melaksanakan tugas, kewajiban, dan pekerjaannya. Untuk lebih jelasnya, pengertian tapa itu dirumuskan dalam naskah Amanat Galunggung (AG, Kropak 632):

“... na urang lanang wadwan, inya twah inya tapa, inya twah na urang, gwaréng twah gwaréng tapa, maja twah maja tapa, rampés twah waya tapa, apan na urang ku twah na mana beunghar ku twah na mana waya tapa, ...

'bagi kita, pria maupun wanita, ya beramal ya bertapa; itulah perbuatan kita. Buruk amalnya berarti buruk tapanya, sedang amalnya berarti sedang tapanya, sempurna 
amalnya berarti sempurna tapanya. Adapun kita ini, karena amalallah dapat menjadi kaya, karena amal pula dapat berhasil tapa kita'.

Dengan demikian, makna tapa itu sama dengan amal. Dalam ajaran agama Islam, amal ibadah mempunyai nilai yang tinggi dalam mengevaluasi kehidupan manusia di dunia. Tinggi-rendahnya derajat manusia, dalam pandangan Tuhan, bukan ditentukan oleh jabatan atau kekayaannya, melainkan oleh ketaqwaan dan amal ibadahnya.

\section{Penutup}

Berdasarkan gambaran pada uraian bagian awal, masyarakat di Tatar Sunda telah mengalami dinamika lintasan perjalanan kehidupan keagamaannya. Pada prinsipnya dapat diakui bahwa proses islamisasi di Tatar Sunda berjalan secara damai, yang antara lain dilakukan melalui pendekatan budaya. Berdasarkan data tradisi naskah Sunda tampak jika proses hinduisasi di Tatar Sunda umumnya bermula dari kalangan atas atau elit keraton, sebaliknya proses islamisasi bermula dari kalangan bawah atau rakyat biasa. Sebagian kalangan elit dan rakyat Sunda bersikap dapat menerima agama Islam dan dengan sukarela mereka masuk Islam.

Adapun yang berkaitan dengan pembahasan mengenai perbandingan pandangan ajaran keagamaan tidak dimaksudkan untuk membandingkan "teks illahiah" (ajaran Islam) dengan "teks insaniah" (konsepsi ciptaan manusia), bukan pula untuk mencari pembenaran salah satu ajaran karena sebagai wahyu Allah, al-Qur'an adalah sumber primer ajaran Islam yang sudah mutlak kebenarannya bagi pemeluknya. Persamaan-persamaan antara dua ajaran seperti terungkap di muka tidak menunjukkan sama sepenuhnya, melainkan hanya makna dan gambaran secara garis besar, dan perbedaan antara keduanya pun tidak sedikit pula.

Pembicaraan dalam tulisan ini dimaksudkan hanya sebagai metode dan pendekatan dalam rangka menjawab dua pertanyaan pada topik pembicaraan bagian kedua. Pembahasan ini, kiranya mencerminkan satu sisi gambaran proses islamisasi orang Sunda dan sedikit banyak telah menjawab dua pertanyaan yang diajukan tadi. Akhirnya, pada bagian akhir tulisan ini dapat dinyatakan bahwa, Islam menjadi pilihan utama dan abadi bagi orang Sunda sekaligus merupakan kesimpulan dari keseluruhan pembahasan ini. 


\section{DAFTAR PUSTAKA}

Atja, 1968, Tjarita Parahijangan: Naskah Titilar Karuhun Urang Sunda Abad ka-16. Bandung: Jajasan Nusalarang.

----. 1986. Carita Purwaka Caruban Nagari: Karya Sastra sebagai Sumber Pengetahuan Sejarah. Bandung: Proyek Pengembangan Permuseuman Jawa Barat.

Atja \& Saleh Danasasmita. 1981, Amanat Galunggung: Kropak 632 dari Kabuyutan Ciburuy Bayongbong-Garut. Bandung: Proyek Pengembangan Permuseuman Jawa Barat.

Atja \& Undang A. Darsa. 1989. Carita Parahiyangan Sakeng Bhumi Jawa Kulwan Sargah 1-4; Transliterasi, Terjemahan Disertai Pendahuluan dan Isi. Bandung-Jakarta: Yayasan Pembangunan Jawa Barat.

Ayatrohaédi, Tien Wartini, Undang A. Darsa, 1987, Kawih Paningkes dan Jatiniskala: Alihaksara dan Terjemahan. Bandung: Bagian Proyek Penelitian dan Pengembangan Kebudayaan Sunda (Sundanologi).

Cortesâo, Armando Z. 1944. The Suma Oriental of Tome Pires: An Account of the East from the Red Sea to Japan Written in Malacca and India in 1512-1515 and the Book of Francisco Rodrigues. Two Vols. London: The Hakluyt Society.

Danasasmita, Saleh \& Ayatrohaédi, Tien Wartini, Undang A. Darsa. 1987.

Sewaka darma, Sanghyang Siksakandang Karesia, Amanat Galunggung: Transkripsi dan Terjemahan. Bandung: Bagian Proyek Penelitian dan Pengkajian Kebudayaan Sunda (Sundanologi).

Direktorat Jenderal Kebudayaan Departemen Pendidikan dan Kebudayaan.

Darsa, Undang A. 1986. Babad Cirebon: Satu Percobaan Rekonstruksi Teks (Skripsi Jurusan Sastra Daerah/Sunda Fakultas Sastra Unpad). Bandung.

----. 1993. Naskah-naskah Sunda: Sebuah Pemahaman Berdasarkan Konvensi Keislaman. Bandung: Lembaga Penelitian Universitas Padjadjaran.

----. 1994. Carita Prabu Kéan Santang: Edisi Teks Dan Terjemahan Disertai Kajian Isi. Bandung: Lembaga Penelitian Universitas Padjadjaran. 
----. 1998. Sang Hyang Hayu: Kajian Filologis Naskah Bahasa Jawa Kuno Di Sunda Pada Abad XVI. Bandung: Tesis Pascasarjana Universitas Padjadjaran.

----. 2012. SÉWAKA DARMA: Suntingan Teks disertai Kajian Intertekstual dalam Naskah Tradisi Sunda Kuno Abad XV-XVII Masehi (SÉWAKA DARMA: Text Edition with Intertextual Studies in the Manuscript from the Old Sundanese Tradition (1 $15^{\text {th }}-17^{\text {th }}$ Centuries). Bandung: PPS FIB Unpad.

Darsa, Undang A. \& Edi S, Ekadjati. 1995. Fragmen Carita Parahyangan dan Carita Parahyangan (Kropak 406): Pengantar dan Transliterasi. Seri Penerbitan Naskah Sunda Nomor 1. Jakarta: Yayasan Kebudayaan Nusantara.

----. 2004. Gambaran Kosmologi Sunda (Kropak 420); Silsilah Prabu Siliwangi, Mantera Aji Cakra, Mantera Darmapamulih, Ajaran Islam (Kropak 421); Jatiraga (Kropak 422). Tokyo: The Toyota Foundation.

Djajadiningrat, Hoesein. 1913. Critische Beschouwing van de Sadjarah Banten. Haarlem: J. Enschede en Zonen. Terjemahan dalam Bahasa Indonesia. 1983: Tinjauan Kritis Tentang Sajarah Banten. Jakarta: Djambatan \& KITLV.

Ekadjati, Edi S. 1995. Kebudayaan Sunda: Suatu Pendekatan Sejarah. Jakarta: Pustaka Jaya.

Ekadjati, Edi S. \& Undang A. Darsa, 1999, Katalog Induk Naskah-naskah Nusantara Jilid 5A: Jawa Barat Koleksi Lima Lembaga. Jakarta: Yayasan Obor Indonesia \& École Française d'Extrême-Orient.

Ekadjati, Edi S. \& Undang A. Darsa, Ayatrohaédi. 2000, Serat Catur Bumi dan Sang Hyang Raga Déwata: Edisi dan Terjemahan Teks serta Deskripsi Naskah. Bandung: Kerja Sama The Toyota Foundation dengan Fakultas sastra Universitas Padjadjaran.

Hageman, J.S.Z. 1867, 1868, 1870. "Geschiedenis der Soendalanden". TBG 16:193-251; TBG 17: 178-257; TBG 19:201-269.

Koentjaraningrat. 1985. Pengantar Ilmu Antropoloogi. Jakarta: Aksara Baru.

Noorduyn, J. \& A. Teeuw. 1999. "A panorama of the world from Sundanese perspective". Archipel 57 II L'horizon nounsantarien, Mélanges en homage à Denys Lombard: 209-221.

----. 2003. Three Old Sundanese Poems. Leiden: KITLV. 
Pigeaud, Th.G.Th. 1924. De Tantu Panggelaran. Een Oud-Javaansh Prozageschrift, uitgegeven, vertaald en toegelicht. 's-Gravenhage: Smits.

Swelenggrebel, J. L. 1937. Korawâçrama: Een Oud-Javaansch Peozageschrift, Uitgegeven, Vertaald en Toegelicht. Santpoort: C.A. Mees.

Zoetmulder, P.J. 1965. "The Significance of the Study of Culture and Religion for Indonesian Historiography" dalam Soedjatmoko, MuhamadAli, G.J. Resink, dan G. Mct. Kahin. An Introduction to Indonesian Historiography. Ithaca-New York: Cornell University Press.

\section{LAMPIRAN}

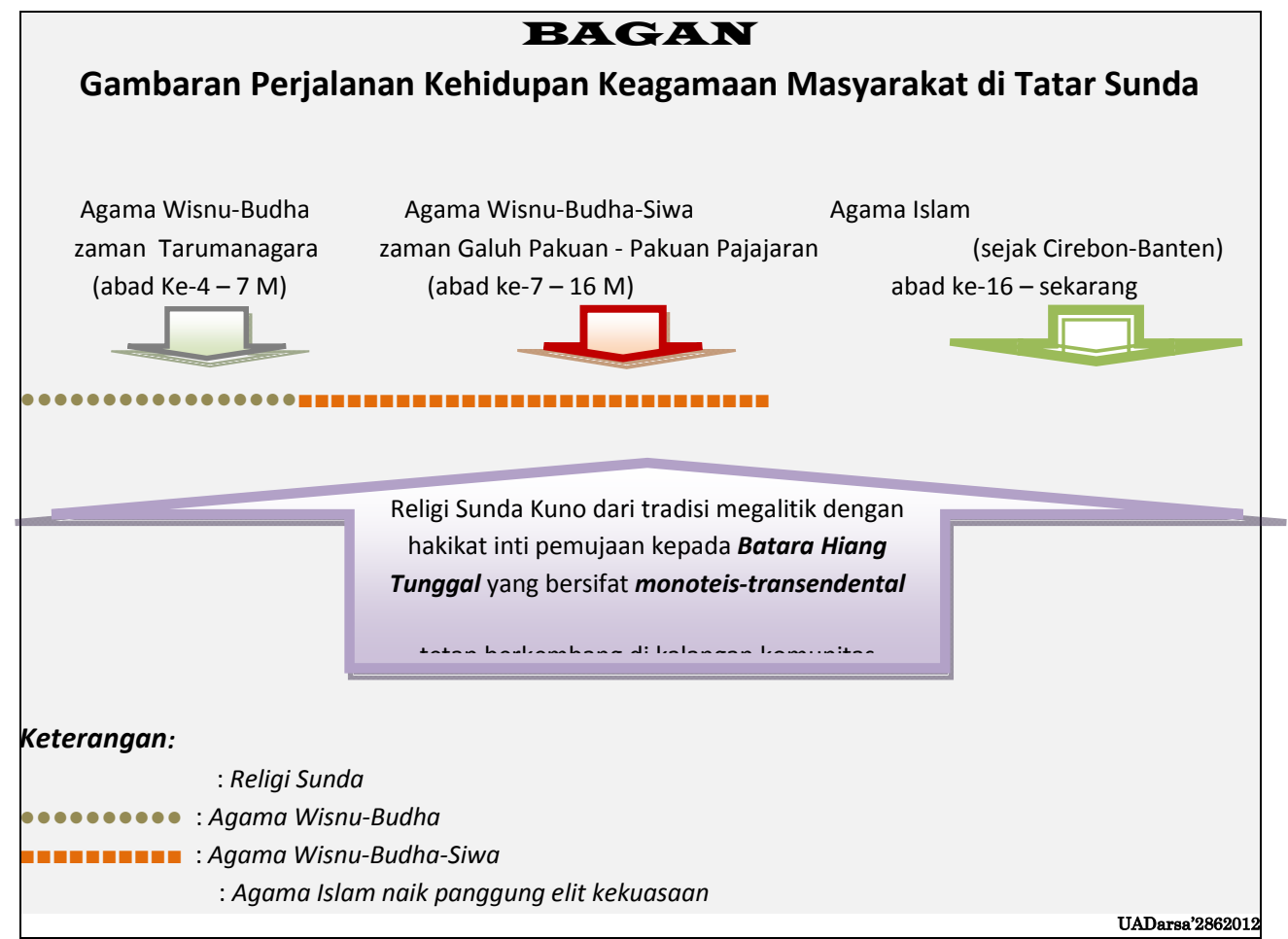


Alam semesta ini pada hakikatnya tanpa batas. Arah penjuru angin, atas maupun bawah hanya ada dalam angan-angan. Di dalam angan-angan itu pula surga berada di atas, dan neraka berada di bawah. Secara garis besar dapat dilihat pada berikut.

Tabel: Konsepsi alam semesta menurut teks naskah Sang Hyang Hayu

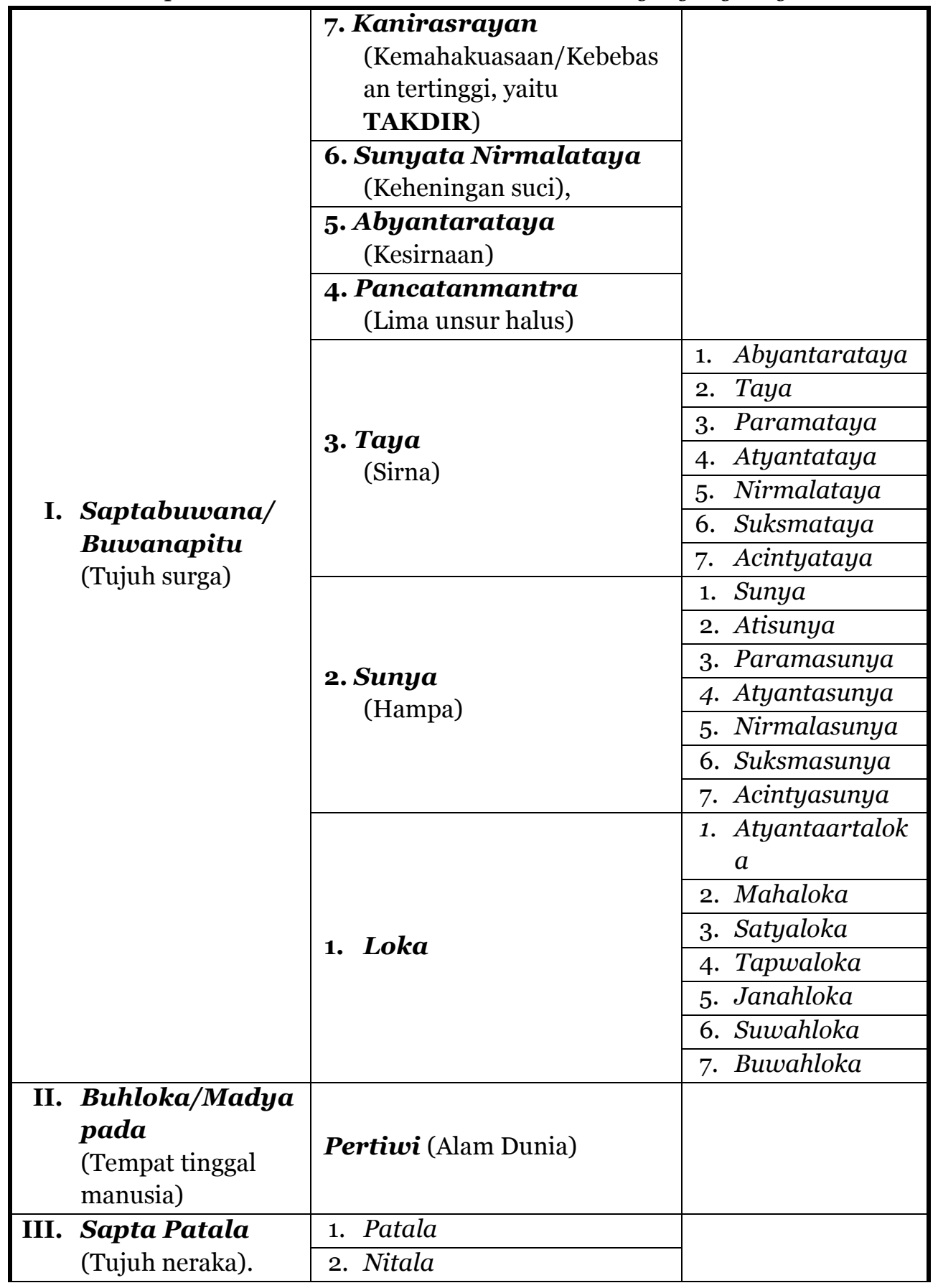


Undang Ahmad Darsa

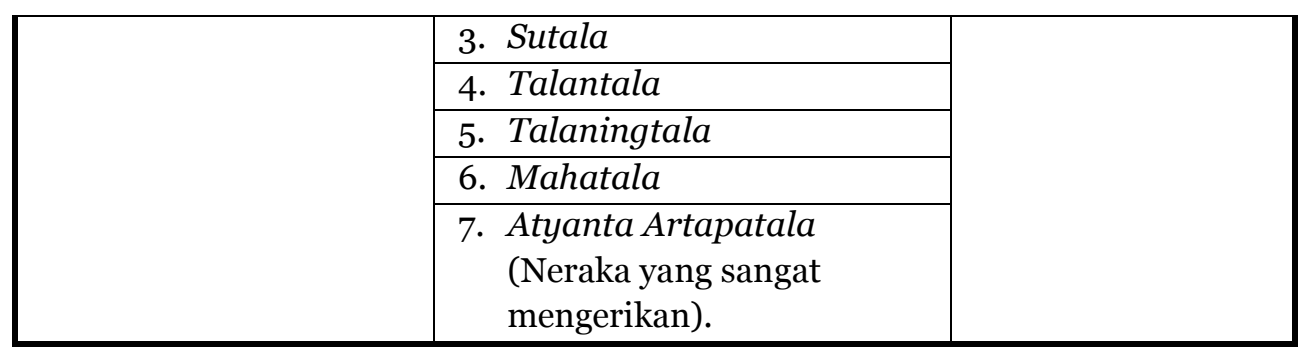

